\title{
Cybercrime Business Digital in Indonesia
}

\author{
Mochammad Fahlevi ${ }^{1, *}$, Mohamad Saparudin ${ }^{1}$, Sari Maemunah ${ }^{1}$, Dasih Irma ${ }^{1}$, and Muhamad Ekhsan ${ }^{2}$ \\ ${ }^{1}$ Department of Management, Faculty of Economics, School of Business Kusuma Negara, Jakarta - Indonesia \\ ${ }^{2}$ Department of Management, Faculty of Economics, School of Business Pelita Bangsa, Cikarang - Indonesia
}

\begin{abstract}
The development of information technology and especially internet communication has caused significant social, economic and cultural changes to occur so quickly. On one side of information technology can provide benefits, simplify and accelerate access to information that we need in all things and can change the model of the economy and business models. However, even a negative impact cannot be avoided. Along with the development of internet technology, causing the emergence of new crimes called new cybercrime through the internet network. In this study, the authors approached qualitatively with interview methods and supported descriptive data from research sources originating from regulators and current digital business people who aimed to find out cybercrime in Indonesia. The results of this study, both regulators and business people view that critical preventive measures are taken and the law must continue to follow the development of crime in the cyber world.
\end{abstract}

Keywords: Cybercrime; Fraud; Business; Digital; Law.

\section{Introduction}

The emergence of worldwide webs has facilitated the production of infrastructure, which is highly developed in the business strategy and operations, due to its contribution to the advancement of businesses in business, thus becoming the primary media for trade and industry development in certain countries and the world at large [1].

Digital technology development has caused the majority of the world's population to get access to the internet, more than four billion people online and $42 \%$ population on social media. 9 out of 10 of all people on social media do not have the chance always to be mobile officials [2]. In addition to access to social media, the ecommerce market is also growing. In January 2015, 28\% of the time was spent online on various social media platforms [2].

The development of technological information and the particularity of internet communication has caused significant social, economic and cultural changes to work quickly. The system can collect, store, process, produce and disseminate information to the public effectively and quickly. Technology is also becoming an alternative, especially for social implementation. The current technology is "weapon", in addition to being able to contribute to improving well-being, progress, human development, such as being valid ways of doing evil. In the dimension of the virtual world, activities are challenging to limit due to very cheap and easily accessible technology from any part of the world. As a result, all people can commit crimes either from the internet or other people who have not connected with those involved.

Digital development is currently fast, like access, that is easier and more affordable to the Internet [3]. Argue that a continuously developing Internet has led to changes in the workforce market and uses marketing strategies. Research has previously stated that traditional markets, such as television, magazines, and radio, where companies try to increase sales are considered to be unstable [3, 4]. Traditional marketers are considered late since the internet has changed the market and has lost effectiveness [4].

According to 2016 survey data released by the Indonesian Internet Network Organizing Association (APJII) [5], 132.7 million Indonesian people have been connected to the internet. It was stated that internet media users in Indonesia continued to increase every year. Ease of access to the internet and easy access to internet devices that make the growth of Indonesian internet users increase. Indonesian internet users 70 per cent of internet users access the internet from mobile devices or mobile gadgets. This shows that the use of mobile internet is quite high, while the use of home internet is quite low.

Besides, the article states that most Indonesian internet users use the internet to access social media and entertainment. Facebook became the destination of most Indonesian internet users and followed by Instagram. Indonesian internet users start providing secure online transactions, using ATMs to transact. Primary goods and services that eliminate online stores such as household equipment and tickets. The user recognizes that the internet is not part of the child and that the government

\footnotetext{
* Corresponding author: fahlevi@stie-kusumanegara.ac.id
} 
must increase the strategy in harmful and immoral affairs.

Still from the APJII survey mentioning that the geographical usage of technology information, Pulau Java still dominates Indonesia's internet penetration followed by Sumatra and Eastern Indonesia in the last position. Users are based on age, ages 10-14 years of penetration 100 per cent, while those over 50 years become the lowest. Based on work, students / private sector workers/health workers record the highest level of users, while entertaining households/workers/ SMEs is the lowest.

The status of information technology can provide benefits, simplify and accelerate information access that is impacted in severe ways that can change the model of the economy and business models. However, the negative impact also cannot be avoided. Along with the development of internet technology, causing new crimes to emerge is called new cybercrime through the internet network.

In Indonesia internet users are overgrowing, based on data from APJII (Indonesian Internet Service Provider Association) in 2017. The number of Internet users in Indonesia in 2017 is 132.7 million users or around 51.5 per cent of the total population of Indonesia at 256.2 million. This is the most crucial part of Indonesia's population using this internet technology. Where 65 per cent of the Java islands or around 86.3 million people and the lowest in Maluku and Papua are 2.5 per cent, around 3.3 million people. From the results of the APJII survey, it was seen the spread of internet users that almost entirely affected all regions in Indonesia. This trend is sufficiently proud because the community service has been able to enjoy developing technology information to be used in life every day.

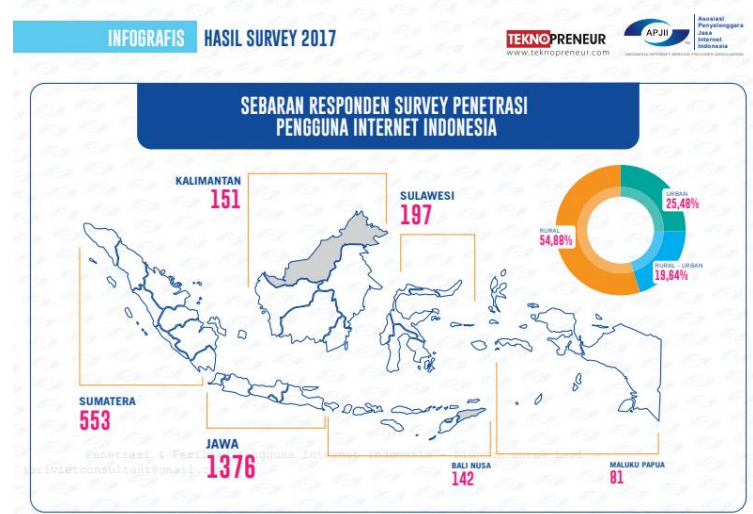

Fig. 1. Data on Internet Users in Indonesia in 2017

\section{Literature Review}

\subsection{Cyber Space}

Cyberspace is an electronic media in a computer network that is widely used for communication purposes in the online marketplace (directly connected). The major world is an integration of various communication technologies and networks of computers (sensors, transducers, connections, transmissions, processors, signals, controllers) that can connect communication equipment (computers, handphones, electronic devices) that are spread all over the world actively.

Cyberspace can also be interpreted as an Imaginary Location (where the electronic activity is carried out) and also becomes a virtual mass formed through steep communication in an interconnected computer network.

Cybercrime is a crime carried out in cyberspace using the computer and technological networks provided by Information and Communication infrastructure. Chawki [6] A visible trend has shown that upbringing of smallscale businesses can increase the value of new challenges posed by cybercrime against welfare for user categories on the internet. According to Jaishankar [7], Cybercrime is now outside the borders and countries that have no or no legislation regarding criminals are increasingly becoming increasingly vulnerable to attacks.

\subsection{Cyber Crime}

Definitions of type and classification of crimes are often different between countries and states. The Cambridge dictionary defines Maya World Crime as Crimes committed by using computers or that relate to computers, primarily via the internet.

Universally, cybercrime is understood as "a lawless act in which a computer is a tool or target or both".

Cybercrime is based on conventional crime as well as a crime; crime and damage in electronic media and from now on the requirements for more equipment are generally regulated under the provisions of the Information Technology Law. The read element of internet crime is that the danger of the alarm at the time of causing the computer to perform a function is that the access is intended to be secured. Do not close the possibility that the user can be classified in more than the category below, or even be supported or support conventional crime.

a) Computer, System, and Network as Weapon

b) Computer systems and networks as the main ones that result in the emergence of individuals, groups, and agencies.

c) Computer, System, and Network as Target

d) Computers, systems, and networks as targets that are attacked often result in problems with individuals, groups, and agencies.

\subsection{Cyber Related Crime}

The evil that is related to the virtual world or the dead can happen outside the network. Cyber-related Crime:

a) Cyber Exacerbated (worsens)

The purpose of exacerbating textures is that someone who uses the internet network for his crime will exacerbate the risk of crime and not use the internet network. For example, pornography.

b) Cyber Assisted (help)

Help in the proxy file for the reverse story, which uses the internet network to help with the crime carried out outside the internet. Like eighth tax. 
Examples of Cyber Related Crime crimes include; piracy of works/infringements, plagiarism, spreads of downloading, such as software or films, illegal content: contradictory content, pornography, hoax content, controversy, sexual harassment, sales of illegal goods (prostitution, drugs). According to Jonathan Roseno in Cyberlaw, the law of internet reminds of the scope of the violation of law in networks, among others:

1. Copyright.

2. Trademark.

3. Defamation

4. Defamation, Defamation, Humiliation (Hate Speech).

5. Attack on computers (Hacking, Viruses, and Illegal Access).

6. External resource management, such as IP-Address, domain name.

7. Comfort Individual (Privacy).

8. Issues of Procedural.

\subsection{Fraud}

Accounting, known as two types of errors and errors. The difference between the two types of errors is distinguished by a fragile gap, that is, or at least a deliberate element. Even if it is known that it often detects more errors, it is difficult to compare with errors while management or work will try to hide it.

"Fraud is a lack of action, which is done in the same way, so that it appears to be alone / group or disadvantages other parties (individuals, companies or institutions)."

Many things encourage the occurrence of a fraud attempt, which is the cause that causes someone to commit fraud (pressure), the opportunity that allows fraud to occur (opportunity), and the essential element in the occurrence of fraud, wherever the search for justification (rationalization).

Types of fraud based on group violations become:

a. Employee fraud (fraud), is a fraud committed by employees in an organization that works.

b. Management fraud (fraud), is a fraud committed by the management by using the financial report or the transaction of the funds for various types of fraud, usually carried out to reduce stakeholders' involvement in the organization.

\subsection{E-Commerce}

Digital business is a business that has the presence (presence) on the internet. "Today, every business is a digital business. "The world is changing around us, and Information and Communication Technologies (ICT) are driving a significant part of this metamorphosis." Accenture at Forbes.

A wave of digital business or various technology technologies has given birth to the phenomenon of business in the face of intelligent and creative intellectual capital. The internet era has made many activities/businesses related to internet developing. At present, many entrepreneurs, business professionals, academics and institutions are investors and investors who have and will engage in activities/businesses that are related to the internet. However, it is marginalized, supported by the government in the field of Information Technology also relatively weak. Infrastructure electronics and communications are very minimal, and even if they are, the sales value is still costly, so it is sometimes memorable as exclusive [8].

In the division of the digital business that relies on the internet in the modern world when digital media is divided into two forms, namely platforms and nonplatforms.

\section{Methodology}

The qualitative research method is a method for investigating subjects that cannot be measured in terms of numbers or other measures of nature. Qualitative research can also be interpreted as a syllabic that is descriptive and tends to use analysis with inductive approaches. Sugiyono [9] describes qualitative research as the naturalistic research method because of his research on natural conditions.

It can be interpreted that in carrying out qualitative research all the research objects are examined for what is manipulation or the setting so that the various conditions of the research objects are useful before, while, and after the research is relatively unchanged.

Qualitative research is a type of study that results in discoveries that cannot be obtained using procedural procedure statistics or the use of quantification. Through research, qualitative researchers can recognize subjects and feel what they experience in daily life. According to qualitative research, definitions produce descriptive data so that they are the details of the phenomenon under study.

According to Indriantoro and Supomo [10], the objectives of this study are to explain the relevant aspects of observed phenomena. The study of collaborative research to explain the characteristics of the subjects under study, examine various aspects of specific phenomena, and offer the idea of problems for further testing or research.

If the study of exploration is intended to understand the characteristics of phenomena or problems studied, this research is intended to explain the characteristics of phenomena or problems that exist.

Table 1. Informant.

\begin{tabular}{|c|c|}
\hline Informant & Status \\
\hline Bima Laga & $\begin{array}{c}\text { Chair of the Digital Economy } \\
\text { Division }\end{array}$ \\
\hline $\begin{array}{c}\text { Muhammad Salahudien } \\
\text { Manggalany }\end{array}$ & $\begin{array}{c}2018 \text { Data Center and Cyber } \\
\text { Security Expert }\end{array}$ \\
\hline $\begin{array}{c}\text { Irjen Pol. Drs. Dharma } \\
\text { Pongrenkun MM, MH. }\end{array}$ & $\begin{array}{c}\text { Deputy for National Cyber and } \\
\text { Password Codes Identification } \\
\text { and Detection }\end{array}$ \\
\hline $\begin{array}{c}\text { Brigjend Pol Rachmad } \\
\text { Wibowo SIK }\end{array}$ & Director of Cyber Crime \\
\hline
\end{tabular}


Descriptive research describes the characteristics of a phenomenon that can be used as a basis for making decisions to solve business problems. This research, although not intended to solve business problems, is also called a diagnosis of analysis whose data can be qualitative data or quantitative. Data collection is always researched; however, sometimes it is also intended to test the hypothesis of the research questions.

Based on the opinion of Karwono and Martadiredja [11], Definitions of research and descriptive analysis are examples to describe the characteristics/symptoms/ functions of the population.

According to Sugiyono [9], the understanding of the research method is as follows:

"The research method can be interpreted as scientific means to obtain valid data with a goal that can be found, developed, and proven, a sense of interest so that in turn it can be used to understand, solve and anticipate problems".

\section{Result}

Based on previous studies, it was found that cybercrime is a global problem. Some developed countries that have large companies in the world-class, especially the ECommerce companies, become the world's largest crime market.

In advanced countries, cybercrime attacks are more likely to be compared to developing countries, so that many countries issue illegal legislation as a preventive step. The resolution of the cluster security in digital business is carried out very seriously and cautious because cybercrime causes a real loss to the company.

The opinions of cybercrime crimes in the online world are also extensive, so most threats to business ecommerce have a high risk of customer data to the theft of account data and payments from customers.

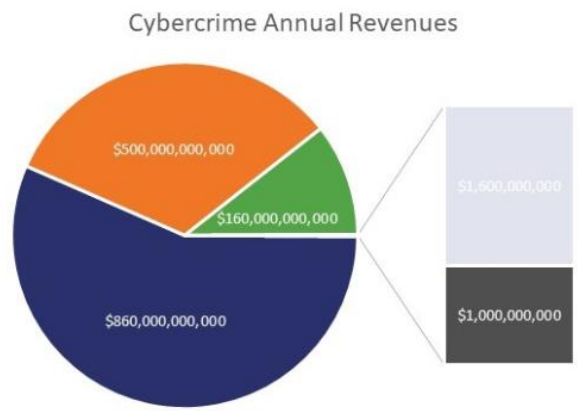

- Illegal online markets " Trade secret, IP theft = Data Trading "Crime-ware/Caas " Ransomware

Fig. 2. Annual Revenues

\subsection{BSSN}

The BSSN drafted the Indonesian Security Strategy as a reference for all the stakeholders in national security in developing and developing security policies in their respective institutions. National security strategies are arranged in harmony with the nature of national and state life, namely: Sovereignty, Independence, Security, Togetherness, and Adaptiveness.
The Government through Presidential Regulation Number 53 of 2017 concerning the State Cyber and Code Body (BSSN) and its amendments. Presidential Regulation Number 133 of 2017 forms the BSSN, which is tasked with carrying out effective and efficient security by utilizing, developing and consolidating all related elements with national security.

Strategic Goals Security Strategy for Indonesia is to provide security, public security, enforcement of security, social security and security for the digital economy. The Security Strategy Indonesian information is expected to be one of the world's trust conditions for Indonesia in various international security forums. The Strategy of Security Indonesia is the contribution of the Indonesian nation in pushing for the creation of world peace.

\subsection{Id-SIRTII / CC}

The idea of establishing Id-SIRTII / CC (Indonesian Security Incident Response Team on the Internet Infrastructure / Coordination Center) was initially delivered by several practitioners, industry, academia, community information technology and government in 2005. ID-SIRTII / CC has the main task of doing socialization with stakeholders about IT Security, carrying out monitoring, detection, warning of threats to network security from foreign countries. Specifically in the act of securing the utilization of the network, creating/running/ developing and log file databases and internet security statistics in Indonesia.

The security of the system information can cause threats, disturbances, and attacks. The book cannot be a complication, such as causing a loss of economy to the high level of service for users. For example, the loss of internet resources in Indonesia has only resulted in a collection of information packages that were sent by parties who were not responsible.

Id-SIRTII / CC also has a supporting agency in law enforcement specifically for crimes that utilize information technology. Especially in the presentation of electronic devices, Id-SIRTII / CC has the facilities, expertise, and procedures to carry out an analysis so that it can make the material of the material being legalized. In a series of investigations, ID-SIRTII / CC has a centralized in giving information on statistics and patterns (incidents) in Indonesian internet traffic.

\subsection{Directorate General of POLRI}

At the National Police Headquarters, the handling of crimes is in the Directorate of Special Economic Crimes (DIT TIPPID EKSUS) in the Directorate V which deals with other acts of crime related to criminal defense, information and electronic transaction transactions. The Directorate of Criminal Investigation, specifically the Metro Jaya Regional Police, is tasked with conducting investigations and investigating specific actions, especially for investigations related to information technology, telecommunications, and electronic transactions. 
By revealing criminal cases that continue to increase from time to time, the Metro Jaya Regional Police Unit appears to be perfecting the disclosure of cybercrime and computers.

With a new model of business activities, e.g. banking, banking, which depend on electronic media, the internet is like the black for cybercriminals. Moving companies are looking for happy online businesses with their growth and on the other side, concerns security. All information and money are threatened by cybercrime.

The e-commerce industry is different in terms of operationalism and has a unique and risky challenge because no physical presence increases the likelihood of fraud and crime. There are many reasons in Indonesia for e-commerce credit that is not controlled. The cost of cybercrime will continue to increase more and more functions of businesses moving online and when consumers and organizations around the world gather in cyberspace. The risk of intellectual wealth theft is increasing, which results in a product with the use of technology thieves leading to enormous losses for companies that are less risky of innovation returns. The government must take the initiative seriously to attack the challenges of cybercrime if not, technology will have an adverse impact on business.

As ideal as President Joko Widodo, Indonesia wants to have more people in Indonesia. The Ministry of Communication and Information, as the presidential assistant also continues to turn MSMEs to have a profile on the internet world.

According to Mr Manggalan, from Id-SIRTII, there has been an interview with the researcher who is aware of the threat of cybercrime in E-Commerce companies and the establishment of cybersecurity systems by eCommerce businesses, especially for the platform.

One more is the establishment of the dispute team. This is good for platforms and non-platforms. Large startups such as Traveloka are one of the most numerous for supervisors.

The Dispute team has the means to provide a misunderstanding. Stake up partners have an anti-fraud division that can decide whether it is fraud or not. For non-platform digital businesses, such as marketing services, social media online shops and others that have profiles, opportunities for threats and threats. Besides, the loss will be paid for in the household or equity.

\section{Conclusion}

Cybercrime is a threat to the world that can cause a loss of life in an ever-increasing attack, which can cause minimal losses. Digital business growth in Indonesia is mainly E-Commerce, along with the crisis in the digital world that can affect digital business in Indonesia. The total loss caused by crime each year reaches $\$ 1.5$ Trillion.

Serious government to develop in Indonesia for the government to prepare the necessary devices such as ITE issues, regulations needed, and related institutions.

Steering related to a digital business must: Knowing 4 Acts - As follows:
First, Government Regulation No. 82 of 2012 concerning the Implementation of Electronic Systems and Transactions. Second, Law No. 19 of 2016 Amendment to Act No. 11 of 2008 concerning Electronic Information and Transactions. Third, Permen Kominfo No. 10 of 2015 concerning Procedures for Registration of Electronic Systems in the State Administration. Fourth, PermenKominfo No. 7 of 2018

Performing management mapping can use the BSSN index and implementation of Standards, ISO 270001, IDSS, and OSO.

Enforcement of law against criminals is still very minimal, making cybercrime free in Indonesia, the problem of regulating and existing laws in Indonesia must continue to be like the other developing countries which are inventive steps from criminals who can find current digital business.

\section{References}

1. S.U. Guan, S.L. Tan, F.A. Hua, modularized electronic payment system for agent-based ecommerce. Journal of Research and Practice in Information Technology, 36(2), 67 (2004)

2. S. Kemp, Digital in 2018: World's internet users pass the 4 billion mark, We are social, 30 (2018)

3. Tiago, Verisimo, Digital Marketing and Social media: Why bother?. Business Horizons, 57(6), 703708 (2014)

4. A. Opreana, S. Vinerean, A new development in online marketing: Introducing digital inbound marketing. Expert Journal of Marketing, 3(1) (2015)

5. A.P.J.I. Indonesia, Infografis Penetrasi dan Perilaku Pengguna Internet Indonesia. ID: APJII (2017)

6. M. Chawki, Nigeria tackles advance fee fraud. Journal of information, Law and Technology, 1(1), 1-20 (2009)

7. K. Jaishankar, Sexting: A new form of Victimless Crime?. International Journal of Cyber Criminology, 3(1), 21 (2009)

8. C.W. Widhianto, E-Business: Teknologi dan Peluang Bisnis di Indonesia. The Winners, 3(1), 1931 (2002)

9. Sugiyono, Metode Penelitian Manajemen. Bandung: Alfabeta, CV (2013)

10. N. Indriantoro, B. Supomo, Metode Penelitian Bisnis. Yogyakarta: BPFE (2002)

11. J. Sarwono, T. Martadiredja, Riset bisnis untuk pengambilan keputusan. Yogyakarta: CV Andi Offset (2008) 